\title{
PROBLEM-BASED LEARNING MATA KULIAH BUSINESS INTELLIGENCE PADA PERGURUAN TINGGI RAHARJA
}

\author{
Padeli $^{1}$ \\ Aris Martono ${ }^{2}$ \\ Aji Kuspriambodo ${ }^{3}$ \\ ${ }^{1}$ Dosen STMIK Raharja, ${ }^{2,3}$ Mahasiswa STMIK Raharja \\ 1,2,3 Jl.Jendral Sudirman No.40,modern,Tangerang,021-5529692 \\ Email :padeli@raharja.infol ${ }^{1}$, aris.martono@raharja.info², ajikuspriambodo@raharja.info ${ }^{3}$
}

\begin{abstract}
ABSTRAK
Perkembangan dunia pendidikan khususnya spesialisasi dibidang bisnis, ekonomi, teknologi informasi dan yang lainnya, mengharuskan setiap tenaga pendidik dan yang dididik harus memiliki jiwa dinamis dan sensitif terhadap perubahan ekonomi dan teknologi yang saat ini sedang banyak dihadapi, yang diketahui banyak dihadapi oleh orang-orang yang menekuni business intelligence (BI). Sehingga dibutuhkan pemahaman lebih mengenai teori, konsep, dan keadaan langsung dilapangan yang nantinya siap dipakai oleh lulusan yang mendalami BI (business intelligence), sehingga tidak terpaku hanya sebatas pemahaman materi, tapi juga contoh kasusnya. Oleh karena itu, diperlukan metode pembelajaran yang menjadikan minat para peserta didik terhadap BI lebih baik sehingga menumbuhkan kemauan mereka dalam menempuh pendidikan ini dan meningkatkan nalar mereka dalam memecahkan studi kasus dalam BI, yaitu dengan menggunakan metode permasalahan sehari-hari, yang didapat dari Problem-Based Learning (PBL) dan Puzzle-Based Learning. Diharapkan dengan menggunakan metode ini peserta didik lebih banyak menyerap materi, teknik dan lebih tertarik terhadap kasus-kasus BI yang terjadi di dunia yang sebenarnya serta mampu untuk berfikir out of the box, secara tidak langsung. Sehingga peserta didik memahami lebih mendalam masalah pada BI baik dalam konteks BI ataupun dalam penerapannya dalam pengambilan keputusan atau perencanaan perancangan model BI itu sendiri sebagai sasaran akhir pembelajaran.
\end{abstract}

Kata kunci : business intelligence, Problem-Based Learning dan keputusan.

\begin{abstract}
Education development, especially in business, economy, and information technology. Having forced every teacher and student to have dinamic and sensitive inhabitant to economic and technology, and it has known that it is faced by business intelligence experts. As a result, more experience about theory, concept, and conditional is necessary. Not only theory, but also the case at least. And we need learning method which grown interest and logical reasoning up in Business Intelligence. By facing daily cases use Problem-Based Learning (PBL) and Puzzle-Based Learning. There is an expectation that students absorb more interest, subject, and case which happened in the real world. Later, they can think out-of-the-box, step by step. Understanding whole concept BI and building model in BI application like decision support or planning building model itself as a main objective.
\end{abstract}

Keyword : business intelligence, Problem-Based Learning and decision 


\section{Pendahuluan}

Menurut Winkel (1996: 53), belajar adalah suatu proses mental/psikis yang berlangsung dalam interaksi aktif dengan lingkungan yang menghasilkan perubahanperubahan dalam pemahaman, keterampilan dan nilai sikap. Perubahan itu relatif konstan dan berbekas dan sebaikbaiknya menggunakan pancaindra.Belajar juga merupakan akumulasi perubahan perilaku dari suatu pengalaman yang telah dialami.

Belakangan ini pembelajaran sebagian masih menggunakan pola yang bersifat transmitif, pengajar mentransfer dan menuangkan konsep-konsep secara langsung pada peserta didik. Dalam hal ini, peserta didik menyerap secara pasif struktur pengetahuan yang diberikan oleh pengajar atau yang terdapat didalam buku pelajaran yang berupa penyampaian fakta, konsep, prinsip, dan keterampilan kepada peserta didik, dan cara ini sebenarnya masih kurang tepat.

Unsur penting dalam pembelajaran ialah merangsang dan mengarahkan peserta didik untuk mau belajar atau mencari pemahaman.Mengajar pada hakikatnya tidak lebih dari sekedar menolong peserta didik untuk memperoleh pengetahuan, keterampilan, sikap, serta ide dan apresiasi yang menjurus kepada perubahan perilaku dan pertumbuhan peserta didik. Salah satu tolak ukur pembelajaran yang baik ialah peserta didik mampu mempelajari apa yang dia harus pelajari, sehingga indikator hasil belajar dapat dipenuhi oleh peserta didik memlalu proses pembelajaran yang tepat oleh tenaga pengajar.

Dalam pembelajaran terdapat istilah pendekatan, strategi, metode, dan teknik.Istilah tersebut harus dipahami oleh tenaga pengajar.Metode bersifat prosedural, dalam arti metode harus dilakukan melalui langkah-langkah yang teratur dan bertahap. Istilah teknik dalam pengajaran mengandung makna cara dan alat yang digunakan tenaga pengajar didalam kelas. Nantinya, tenaga pengajar harus menemukan pendekatan yang tepat, lalu menentukan metode yang tepat dengan tujuan pembelajaran, baru memikirikan daya upaya menyampaikan bahan tersebut kepada peserta didik.

Problem-Based Learning (Savery, 2006) adalah pendekatan pembelajaran yang mendukung berfikir kreatif atas permasalahan sehari-hari dengan pemikiran yang terbuka. Dan

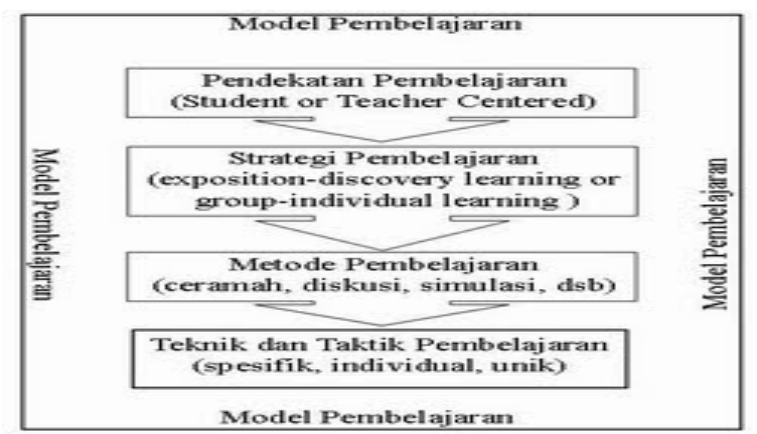

Gambar 1.0 Model Pembelajaran business intelligence

puzzle-based learning akan membuat situasi belajar BI menjadi lebih menyenangkan dan memotivasi mereka dengan membuat peserta didik berfikir "out of the box". Pendekatan yang kita gunakan ialah masalah kehidupan seharihari yang biasa dihadapi orang-orang pada umumnya dan membuat teka-teki dalam masalah tersebut. Kemudian peserta didik menyelesaikan masalah dengan beberapa penyelesaian masalah, yang nanti akan membuat para peserta didik memiliki rasa keingintahuan yang nantinya akan membuat mereka bertanya. 
Menurut H. Peter Luhn (1958), BI (Business Intelligence) mendefinisi-kannya sebagai kemampuan dalam mengerti dan memahami suatu hubungan

timbal balik antara fakta-fakta yang disajikan sedemikian rupa menjadi suatu landasan dalam bertindak untuk mencapai tujuan yang dikehendaki. BI pada dasarnya me-miliki dua arti berbeda dalam penggunaannya atau peng-aplikasiannya. Yang pertama me-miliki arti sebagai kemampuan manusia yang diaplikasikan

\section{Metode Penelitian}

Metode penelitian yang dalam penelitian ini adalah studi kasus. Dengan menggunakan metode yang telah ada dan telah dikembangkan, nantinya akan dipadukan untuk membuat suatu metode pengajaran yang lebih efektif. Dikatakan efektif bilamana tenaga pengajar mampu membangun metode pembelajaran dengan pendekatan konstruktivisme.Menurut Depdiknas (2003) pendekatan kontruktivisme ialah pendekatan yang menekankan bahwa belajar tidak hanya menghapal, dan peserta didik harus mengkontruksikan atau membangun pengetahuan mereka sendiri.

Selain itu, penelitian juga menggunakan metode observasi non-participant. Yaitu dengan ikut menjadi bagian dari peserta didik lalu mengamati bagaimana keadaan di kelas saat itu. Dimana di kelas ter-sebut metode pembelajaran menggunakan metode pembelajaran konvensional (ceramah). dalam aktivitas bisnis, dan yang kedua berkaitan dengan kecerdasan sebagai informasi yang ter-kandung berdasar nilai dan relevansinya.BI juga merupa-kan informasi tingkat lanjut, pengetahuan, dan penggunaan teknologi secara efisien dalam manajemen organisasi ataupun bisnis pribadi.Dengan tujuan utama untuk mendukung keputusan untuk sebuah organisasi, dengan menyediakan akses ke data yang ada.

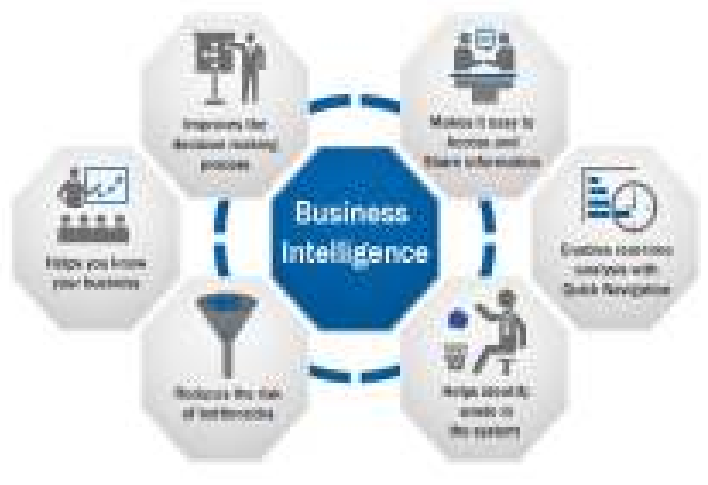

Gambar 2.0 Pemahaman mengenai business intelligence

\section{Permasalahan}

Dewasa ini, analisa bisnis dalam dunia bisnis atau organisasi bisnis menjadi sangat vital karena sangat berpengaruh terhadap kelangsungan perusahaan tersebut dalam jangka pendek ataupun jangka panjang.Analisa bisnis yang secara langsung ataupun tidak langsung yang terkandung dalam mata kuliah BI menjadi sangat penting karena dalam praktiknya sangat dibutuhkan oleh para pelaku usaha.Dikarenakan, metode pembelajaran yang dinilai masih kurang tepat dan terlalu banyaknya teori daripada praktik tentang 
bagaimana pengaplikasian business

Minat dan ketertarikan peserta didik menjadi sangat hal yang riskan, karena latar belakang peserta didik yang berbeda, lalu di antara peserta didik ada yang sudah bekerja, ketertarikan yang kurang, kemajuan teknologi menjadi faktor-faktor internal yang menyebabkan peserta didik menjadi kurang tertarik. Adapun faktorfaktor eksternal seperti metode pembelajaran yang masih kurang menarik, penyalahgunaan koneksi wi-fi, dan terlalu banyak teori, juga menjadi faktor-faktor penting dalam menunjang minat peserta didik terhadap konsep dan teknik dalam BI. Pemahaman BI dlam dunia kerja tidak hanya sebatas pada teori, namun juga mereka yang mempelajarinya harus memahami ilmu praktis dari BI itu sendiri seperti data warehouse, decision support system, dan data mining. Pemahaman mendalam dan seimbang antara teori dan ilmu lapangan sangat penting sebagai bekal mereka dalam mengembangkan ilmu intelligence itu sendiri.

mereka sebagai data analyst, business analyst atau warehouse management.

Kegiatan Belajar Mengajar (KBM) pada pertenaga pengajaran tinggi Raharja, khususnya pada kelas i-Learning dengan sarana tablet sebagai media pembelajaran jarak jauh dimana dapat digunakan sebagai tele-classing (kelas jarak jauh) atau sebagai media untuk ujian online. Sayangnya penggunaan media tablet seperti ini belum tampak menunjukkan hasil yang positif walaupun trend yang ada berbanding terbalik. Salah satu android marketplace developer merilis infografik mengenai kecenderungan aliran data jaringan masyarakat Indonesia pada tahun 2015, fakta menarik bahwa sekitar 43 persen masyarakat Indonesia lebih memilih mengunduh aplikasi permainan dan sosial media $(12,02 \%)$ dibanding dengan aplikasi yang menunjang pembelajaran seperti aplikasi berbasis buku $(2,72 \%)$ dan productivity $(2,31 \%)$.

\section{Infographic of mobile Internet users' interests/habits}

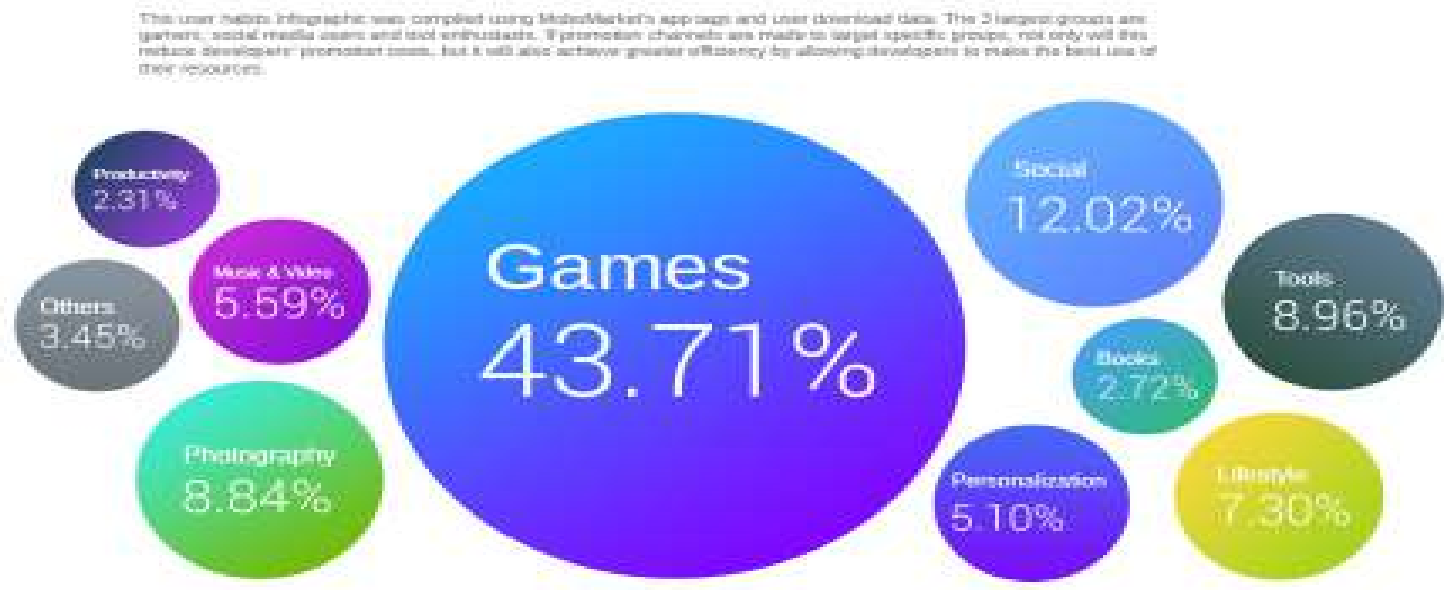

Gambar 1.0 Infografik ketertarikan masyarakat Indonesia terhadap aplikasi

Penggunaan tablet sebagai media pembelajaran jarak jauh nampaknya masih perlu perhatian dari para tenaga pengajar.
Salah metode pembelajaran maka fokus peserta didik akan malah ke sesuatu yang 
lain dan dapat berakibat turunnya kualitas dan kuantitas dari peserta didik.

Oleh karena itu, pengoptimalan sumber daya manusia yang ada, dalam hal ini adalah tenaga pengajar berperan sangat penting, karena mereka dituntut untuk bisa menciptakan suasana yang kondusif, namun ilmu yang diserap oleh peserta didik juga optimal. Dengan metode konvensional yang dinilai kurang tepat dengan kondisi masyarakat saat ini dalam mengembangkan potensinya, menggunakan metode - metode pembelajaran baru yang lebih dinamis menjadi salah satu alternatif penyelesaian masalah, seperti metode PBL. Sehingga pengoptimalisasian metode pembelajaran tenaga pengajar dengan fokus peserta didik dapat di lakukan dan membuat lulusan mahasiswa dengan konsentrasi BI dapat lebih berkompeten dalam pemahamannya mengenai BI dan terapan ilmu di dalamnya.

\section{Literature Review}

Penelitian dan pengembangan tentang metode pembelajaran sudah banyak dilakukan oleh banyak peneliti di seluruh dunia, bagaimana mereka menyajikan data dan menganalisa, sehingga mampu menciptakan inovasi-inovasi baru dalam dunia pendidikan.Dalam pengembangan karya tulis ini, menjadi sangat penting karena menjadi salah satu penerapan metode penelitian ini. Beberapa Literature review tersebut adalah:

1. Penelitian ini dilakukan oleh Wanda Presthus dan Bendik Bygstad, berjudul "Business Intelligence in College: A Teaching Case with Real Life Puzzles" pada tahun 2012. Penelitian ini mengembangkan konsep puzzle dalam memberikan kasus kepada mahasiswanya dengan metode PBL. Pada penelitian juga dibahas bagaimana menarik minat peserta didik dengan menggunakan metode puzzle-based, dan problem-based dengan batasan persoalan kehidupan manusia seharihari sehingga mampu menarik minat peserta didik.Dan hasil akhirnya, peserta didik mampu berfikir dan analisa secara logis dalam menghubungkan puzzle-based dengan BI query.

2. Penalitian berjudul "Peningkatan Model dan Hasil Belajar Siswa Melalui Model Problem Based Learning (PBL)" oleh Vivin Nurul Agustin pada tahun 2012. Hasil belajar siswa SD Negeri 01 Wanarejan tahun 2010/2011 rendah karena penyampaian materi yang masih didominasi metode ceramah. Penelitian ini bertujuan untuk meningkatkan hasil dan aktivitas belajar siswa dan penampilan tenaga pengajar pada materi pecahan melalui model PBL di SD Negeri 01 Wanarejan Pemalang. Penelitian ini menggunakan desain penelitian tindakan kelas yang dilakukan dalam dua siklus. Setiap siklusnya terdiri dari empat tahap, yaitu perencanaan, tindakan, observasi, dan refleksi. Teknik pengumpulan data dilakukan melalui tes (tes formatif) dan non tes (observasi dan dokumentasi). Dapat disimpulkan bahwa model PBL dapat meningkatkan hasil dan aktivitas belajar siswa serta performansi tenaga pengajar dalam pembelajaran matematika materi pecahan di SD Negeri 01 Wanarejan Pemalang.

3. Jurnal yang berjudul "Problem-Based Learning for Foundation Computer 
Science Courses" oleh Mike Barg, Alan Fekete, Tony Greening, Owen Hollands, Judy Kay, and Jeffrey $\mathrm{H}$. Kingston. Dalam penelitiannya mereka menjelaskan tentang tantangan dalam menggunakan metode PBL dan bagaimana mendesain PBL untuk menarik minat peserta didik maupun tenaga pengajar. Masalah yang didiskusikan dalam jurnal ini ialah: banyaknya fokus teknikal di banyak kelas; permasalahan belajar individual dan dasar-dasar yang dirasa penting untuk diketahui oleh lulusannya. dan selama 3 tahun penelitian, dapat disimpulkan bahwa PBL mampu mendapatkan kemampuan yang dibutuhkan dalam object-oriented programming, penyelesaian masalah, belajar mandiri, kemampuan research, menulis, dan presentasi lisan.

4. Penelitian oleh Zbigniew Michalewicz, Matthew Michalewicz yang berjudul "Puzzle-Based Learning" pada tahun 2007. Ide dari penulisan jurnal ini ialah untuk meningkatkan kemampuan matematika dan kemampuan problemsolving dengan menggunakan beragam puzzle (teka-teki). Dan hasilnya, metode Puzzle-Based Learning sangat bermanfaat dalam kasus matematika, cara berfikir kritis, dan kemampuan problem-solving.

5. Penelitian yang berjudul "Pembelajaran Berbasis Masalah (Problem Based Learning) oleh Dindin Abdul Muiz Lidinillah. Permasalahan yang sering muncul dalam dunia pendidikan ialah lemahnya lemahnya siswa dalam menggunakan kemampuan berfikirnya. Seringnya siswa hanya dituntut menghafal dan sering kali tidak sesuai dengan relevansi ataupun kenyataan yang ada. Oleh karena itu, tenaga pengajar perlu merancang pembelajaran yang mampu membangkitkan potensi siswa dalam kemampuan berfikirnya untuk menyelesaikan sebuah masalah. Berdasarkan latar belakang tersebut perlu kiranya merumuskan topik-topik masalah sebagai pijakan untuk terfokusnya kajian tentang Pembelajaran Berbasis Masalah. Adapun topik masalahnya adalah tentang: konsep dasar pembelajaran berbasis masalah; karakteristik pelaksanaan pembelajaran berbasis masalah; langkah - langkah pembelajaran berbasis masalah; penilaian dalam pembelajaran berbasis masalah; dan kelebihan dan kekurangan pembelajaran berbasis masalah.

\section{Penyelesaian Masalah}

Melihat kesempatan bahwa BI menjadi salah satu komponen penting dalam kehidupan bisnis dan usaha, namun berbanding terbalik dengan metode pembelajaran yang ada, maka dengan menggunakan metode pembelajaran yang baru yang lebih dinamis. Untuk menyelesaikan permasalahan yang ada, maka diperlukan suatu proses belajar yang membuat perhatian peserta didik lebih tertuju kepada tenaga pendidik daripada ke gadget yang ada, dan bagaimana cara tersebut bertahan selama satu pertemuan penuh. Saat ini, para tenaga pengajar lebih memilih cara konvensional dalam mengajar daripada menggunakan cara lain yang sebenarnya lebih baik, sebagai hasilnya para peserta didik kurang ertarik terhadap materi yang disampaikan oleh dosen. 
Problem-Based Learning dan PuzzleBased Learning menjadi pilihan ketika model konvensional tidak berhasil karena cocok dengan materi yang ada dimana para peserta didik diharuskan bertanya dan berfikir dengan logika kompleks untuk menyelesaikan persoalan, dimana permasalahan yang ada, dibatasi oleh permasalahan yang biasa dihadapi seharihari oleh masyarakat ataupun peserta didik itu sendiri, sehingga mereka akan merasa tertantang dan tertarik untuk menyelesaikan masalah tersebut.

Adapun karakteristik PBL menurut Rusman (2010: 32), yaitu:

a. permasalahan menjadi starting point dalam belajar

b. permasalahan yang diangkat adalah permasalahan dunia nyata yang tidak terstruktur

c. permasalahan membutuhkan perspektif ganda

d. permasalahan menantang pengetahuan yang dimiliki peserta didik, sikap, dan kompetensi, yang kemudian membutuhkan identifikasi kebutuhan belajar dan bidang baru dalam belajar

e. belajar pengarahan diri menjadi hal yang utama

f. pemanfaatan sumber pengetahuan yang beragam, penggunaannya, dan evaluasi sumber informasi merupakan proses yang esensial dalam Problem Based Learning

g. belajar adalah kolaboratif, komunikasi, dan kooperatif

h. Pengembangan keterampilan inquiry dan pemecahan masalah sama pentingnya dengan penguasaan isi pengetahuan untuk mencari solusi dari sebuah permasalahan. i. Sintesis dan integrasi dari sebuah proses belajar

j. Problem Based Learning melibatkan evaluasi ddan review dari pengalaman peserta didik dan proses belajar

Dengan menerapkan metode ini, diharapkan tenaga pengajar mampu memberikan ruang gerak berfikir ke segala arah. Maksudnya ialah ketika permasalahan diberikan, peserta didik tidak terbatas dalam memecahkan masalah, dan mampu berfikir out-of-the-box. Disamping itu, tenaga pengajar juga diharuskan mampu menciptakan lingkungan belajar sebagai suatu system sosial yang memiliki ciri proses demokrasi dan proses ilmiah, dimana interaksi dua arah harus diterapkan dan komunikasi harus jelas sehingga akan timbulnya proses diskusi, interupsi (ketidaksetujuan terhadap pendapat yang diutarakan oleh pihak lain), dan evaluasi. Sehingga peserta didik mampu berfikir secara luas dan memahami masalah secara konsep, bukan materi.

Proses pengaplikasian tersebut, terbagi dalam 6 tahap, yaitu:

Fase 1: Pengajuan permasalahan dan peserta didik terbagi dalam beberapa kelompok. Soal yang diajukan seperti dinyatakan sebelumnya harus tidak terstruktur dengan baik, dan memungkinkan penyelesaiannya memerlukan informasi atau data lebih, serta memungkinkan banyak cara atau jawaban.

Fase2: Apa yang diketahui dari permasalahan? Dalam fase ini setiap peserta didikakan melihat permasalahan dari segi pengetahuan yang telah dimiliki sebelumnya. Kelompok akan mendiskusikan dan menyepakati batasan - batasan mengenai permasalahan tersebut, serta memilih isu isu yang cukup beralasan untuk diselidiki 
lebih lanjut. Analisis awal ini harus menghasilkan titik awal untuk penyelidikan dan dapat direvisi apabila suatu asumsi dipertanyakan atau informasi baru muncul.

Fase 3: Apa yang tidak diketahui dari permasalahan? Disini anggota kelompok akan membuat daftar pertanyaan-pertanyaan atau isu-isu pembelajaran yang harus dijawab untuk menjelaskan permasalahan. Dalam fase ini anggota kelompok akan mengurai permasalahan menjadi komponen - komponen, mendiskusikan implikasinya, mengajukan berbagai penjelasan atau solusi, dan mengembangkan hipotesis kerja. Kegiatan ini seperti fase "brainstorming" dengan evaluasi; penjelasan atau solusi dicatat. Kelompok perlu merumuskan tujuan pembelajaran, menentukan informasi yang dibutuhkan, dan bagaimana informasi ini diperoleh.

Fase 4: Alternatif Pemecahan. Dalam fase ini anggota kelompok akan mendiskusikan, mengevaluasi, dan mengorganisir hipotesis dan mengubah hipotesis. Kelompok akan membuat daftar "Apa yang harus dilakukan?" yang mengarah kepada sumberdaya yang dibutuhkan, orang yang akan dihubungi, artikel yang akan dibaca, dan tindakan yang perlu dilakukan oleh para anggota. Dalam fase ini anggota kelompok akan menentukan dan mengalokasikan tugastugas, mengembangkan rencana untuk mendapatkan informasi yang dibutuhkan. Informasi tersebut dapat berasal dari dalam kelas, bahan bacaan, buku pelajaran, perpustakaan, perusahaan, video, dan dari seorang pakar tertentu.Bila ada informasi

Dalam penerapannya, diharapkan pengaplikasian mengandung 3 aspek yang terhubung ke dalam Problem-Based Learning baru, kelompok perlu menganalisa dan mengevaluasi reliabilitas dan kegunaannya untuk penyelesaian permasalahan yang sedang dihadapi.

Fase 5: Laporan dan Presentasi Hasil. Pada fase ini, setiap kelompok akan menulis laporan hasil kerja kelompoknya. Laporan ini memuat hasil kerja kelompok dalam fase - fase sebelumnya diikuti dengan alasan mengapa suatu alternatif dipilih dan uraian tentang alternatif tersebut.Pada bagian akhir setiap kelompok menjelaskan konsep yang terkandung dalam permasalahan yang diajukan dan penyelesaian yang mereka ajukan. Laporan ini kemudian dipresentasikan dan didiskusikan.

Fase 6: Pengembangan Materi. Dalam fase ini tenaga pengajar akan mengembangkan materi yang akan dipelajari lebih lanjut dan mendalam dan memfasilitasi pembelajaran berdasarkan konsep-konsep yang diajukan oleh setiap kelompok dalam laporannya.

\section{Problem-Based Leaming Process}

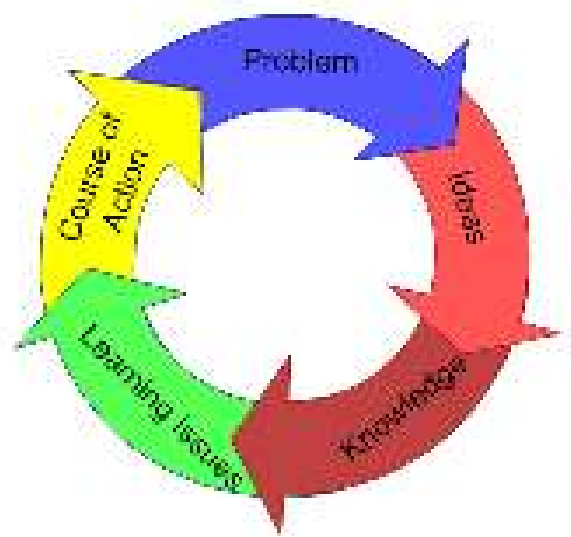

Gambar 2.0 Siklus Process Based Learning dan Puzzle-Based Learning dalam konteks BI, yaitu: 
1. Real Life Problem: berdasarkan Problem-Based Learning, sebuah masalah seharusnya terstruktur dan berasal dari permasalahan yang pernah ada, dimana memotivasi peserta didik untuk mencari solusinya (Saveri, 2006).

2. Real Life Data: yang kedua, BI sering dikaitkan dengan volume data yang besar, sebagai contohnya Point-Of-Sale (POS) pada toko (Davein et Al..., 2001). Fakta ini mempresentasikan

\section{Kesimpulan}

Dengan menerapkan metode PBL, ketertarikan peserta terhadap materi yang diberikan oleh tenaga pengajar mampu ditingkatkan karena pendekatan yang kontruktif dan komunikatif, sehingga membuat daya tangkap para peserta didik menjadi lebih baik dan mengurangi kebosanan para peserta didik, adapun beberapa keunggulan metode PBL ini ialah:

a. membuat peserta didik menjadi lebih kreatif dalam berfikir

b. kedekatan yang lebih terjalin antara tenaga pengajar dan peserta didik, sehingga membuat suasana belajar yang lebih kondusif

\section{Daftar Pustaka}

[1] Agustin, Nurul Vivin. Peningkatan Aktivitas dan Hasil Belajar Siswa Melalui Model Problem Based Learning (PBL), http://journal.unnes.ac.id/sju/inde x.php/jee.Semarang: Universitas Negeri Semarang, Indonesia. 2013. masalah yang unik dari sebuah data yang besar.

3. Real Life Solutions: dan yang terakhir, Puzzle-Based Learning menekankan bahwa aspek menarik atau yang menonjol dari sebuah masalah ditentukan dengan fakta bahwa masalah tersebut hanya ada satu solusi. Solusi dari masalah tersebut bisa sangat mengejutkan, namun tetap berdasar atas data yang disajikan.

c. penguasaan materi yang lebih baik daripada metode konvensional

d. standar kompetensi yang lebih mudah dicapai

namun, dalam pengaplikasiannya bukan berarti metode ini adalah metode yang paling tepat, karena masih terdapat banyak keterbatasan, diantaranya:

a. adaptasi tenaga penagajar dan peserta didik yang kadang membutuhkan waktu yang lama

b. perubahan peran antara tenaga pengajar dan peserta didik

c. perumusan masalah yang tepat untuk peserta didik.
[2] Imelda, S.T, M.T. Business Intelligence, Majalah Ilmiah UNIKOM volume 11 No 1. Indonesia: Prodi Sistem Informasi, FTIK, UNIKOM.

[3] Lidinillah, Dindin Abdul Muiz. Pembelajaran Berbasis Masalah (Problem Based Learning)[online]. 2014. 
[4] Martono, Strategi Pembelajaran (Pengantar Kajian Pembelajaran Efektif). Jurnal Visi Ilmu Pendidikan. FKIP, Untan.

[5] Michalewicz, Zbigniew and Michalewicz, Matthew. PuzzleBased Learning, Melbourne: AaaE Conference. 2007.

[6] Pallenari, Muhidin. Potensi Strategi Integrasi PBL Dengan Pembelajaran Kooperatif Jigsaw Dalam Meningkatkan Pemahaman Konsep Mahasiswa.Jurnal Ilmiah Pendidikan Biologi, Biologi Edukasi Volume 3 No 2, Desember 2011. Makassar: Jurusan Biologi, FMIPA, Universitas Negeri Makassar, Indonesia.

[7] Presthus, Wanda and Bygstad, Bendik.Business Intelligence in College: A Teaching Case with Real Life Puzzles, Journal of Information Technology Education: Innovations in Practise, Oslo: Norwegian School of IT. 2012.
[8] Problem-Based Learning (online), Stanford University Newsletter on teaching vol 11 No 1. Stanford University. 2011.

[9] Ranjan, Jayanthi. Business Intelligence: Concepts, Components, Techniques, and Benefits. Journal of Theorical and Applied Information Technology. India: Institute of Management Technology. 2008.

[10] Y, Leonardus Pandu baskoro, Penerapan Model Problem Based Learning Untuk Meningkatkan Keaktifan dan Hasil Belajar Siswa pada Pelajaran Komputer (KK6) di SMK N 2 Wonosari Yogyakarta. Yogyakarta: Universitas Negeri Yogyakarta. 2013.

http://www.slideshare.net/BaiduIn donesia/q2-2015-indonesiamobile-data-report-based-on-

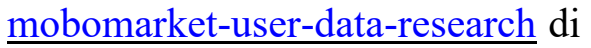
akses pada tanggal 26 Oktober 2015. 